\title{
REFLECTIONS
}

\section{Dear White People}

Krys E. Foster, MD, MPH, FAAFP ${ }^{1}$

Christina N. Jobnson, MD, $P b D^{2}$

Diana N. Carvajal, MD, $M P H^{3}$

Cleveland Piggott, MD, MPH

Kristin Reavis, $M D, M S^{3}$

Jennifer Y. C. Edgoose, MD, MPH

Tricia C. Elliott, MD, FAAFP'

Marji Gold, $M D^{7}$

José E. Rodríguez, MD, FAAFP

Judy C. Washington, MD, FAAFP ${ }^{2}$

'Department of Family and Community Medicine, Thomas Jefferson University,

Philadelphia, Pennsylvania

${ }^{2}$ Overlook Family Medicine Residency

Program, Summit, New Jersey

${ }^{3}$ Department of Family and Community Medicine, University of Maryland School of Medicine, Baltimore, Maryland

${ }^{4}$ Department of Family Medicine, University of Colorado, Aurora, Colorado

${ }^{5}$ Department of Family Medicine and Community Health, University of Wisconsin School of Medicine and Public Health, Madison, Wisconsin

${ }^{6} J P S$ Health Network, Fort Worth, Texas

${ }^{7}$ Department of Family and Social Medicine, Albert Einstein College of Medicine Bronx, New York

${ }^{8}$ University of Utah Health, Salt Lake City, Utah

Conflicts of interest: authors report none.

\section{CORRESPONDING AUTHOR}

Krys E. Foster, MD, MPH, FAAFP

1015 Walnut Street, Suite 401

Philadelphia, PA 19107

Krys.Foster@jefferson.edu

\begin{abstract}
We are living in unprecedented times. While the world is grappling with COVID19, we find the horrors of racism looming equally large as we, yet again, confront lurid deaths in the center of the news cycle of Black and brown people from police bias and brutality. Those of us who have been championing antiracism and justice work and bearing the burden of the "minority tax" have been overwhelmed by sudden asks from our well-intentioned White colleagues of how to best respond. In the tone of the Netflix series, "Dear White People," we further emphasize that we are not alone in trying to reach out to you, our White colleagues and leaders. Please hear our story and heed our call to action.
\end{abstract}

Ann Fam Med 2021;19:66-68. https://doi.org/10.1370/afm.2634.

$\mathrm{D}$ ear White People,

We come to you as family physicians on the frontline caring for the most vulnerable in our communities; as educators teaching the best and brightest; ${ }_{i}$ as scientists seeking novel ways to achieve health equity; as parents of children of all different hues; as survivors of an unjust world; and as leaders who have been fighting for social justice for decades.

We are tired.

Those of us who are people of color are as unsurprised as we are outraged over the murders of George Floyd, Breonna Taylor, Tony McDade, Ahmaud Arbery, Rayshard Brooks, and so, so many more unarmed Black and brown people. Although the world now shares in our revulsion toward the pandemic of systemic and individual anti-Black racism, many of us carry the lived experience of centuries-old endemic racism. Those of us who are minority physicians are not immune to its vestiges. We arrive at clinical and teaching practices having navigated unbalanced and biased primary, secondary, and higher education systems, including medical schools, with scant representations of ethnically concordant teachers and colleagues. We emerge with higher financial debt than our peers yet disproportionately migrate to communities of socioeconomic distress to care for the underserved and marginalized in greater numbers than our White colleagues. We produce essential works that highlight gaps in care for these communities and tools by which to address such gaps, ${ }^{1}$ and yet we are undervalued, ${ }^{2}$ underpaid ${ }_{1}{ }^{3}$ clinically overburdened ${ }_{,}{ }^{4}$ and denied career advancement. We are subjected to macro- and microaggressions dailysubtle, intentional or often unintentional, behaviors and interactions with both colleagues and patients that are rife with racial bias. We bear the burden of the "minority tax, ${ }_{1}^{14}$ carrying the responsibility of educating our colleagues in medicine, leading diversity efforts in mentoring and recruitment, in addition to clinical responsibilities including care of the underserved while practicing in under-resourced areas. Minority clinicians and their allies are tasked with "explaining" and then "fixing" racism and 
the inequities associated with racism in medicine while balancing the complexities of White fragility. If you do not see us present at contemporary racial justice rallies, it is because we are few, we are likely working, and we are tired.

As authors of this commentary, we refuse to move into this new sociopolitical moment continuing to have our fellow minority colleagues bear the sole responsibility for change. The goal of our work is to actively combat racism in medicine and society at large, and we write this piece to recruit more allies to join the effort.

We are tired.

Many people of color and their anti-racist White allies knew early on that coronavirus disease 2019 (COVID-19) was not going to be a great equalizer. The pandemic has only amplified that Black, Latinx, Indigenous, and immigrant communities are solidly on the wrong side of the disparity statistics. Black Americans assume the greatest mortality rate from COVID-19 at 2.4 times that of White Americans ${ }^{5,6}$; Latinx people have the greatest rates of unemployment accounting for $57 \%$ of jobs lost in March and April of this year ${ }^{7}$; while the Navajo Nation has the highest COVID-19 infection rate in the United States. ${ }^{8}$ COVID-19 is colorblind, however, the factors that lead to poor outcomes such as inequities in education, insurance status, and access to health care are not. People marched in the streets because of the murders of Black men and women, while marching through the same neighborhoods where anti-Black racism created the risk factors which fueled the flames that contributed to the rampant spread of the virus. We march with exasperation over persistent inequities across the leading causes of morbidity and mortality as our simmering resentment, anger, grief, and pain rise to a boil.

We are tired.

We speak specifically to you, our White colleagues. Rise up now and claim solidarity with Black, Indigenous, and other people of color (BIPOC) who are having shared histories of inequity, racism, and bias, and proclaim that you see them and hear them. Express outrage about the persistence and pervasiveness of racism. Express your desire to help magnify the message of the chronically oppressed and abused without making martyrs of people of color and their allies who have consistently carried this heavy and lopsided burden. Most importantly, include, support, and elevate the voices of all people of color in your attempts to break down the systemic policies and practices that fuel the current state of affairs.
So, what can those of you who want to serve as allies do?

- Listen to Black people and other people of color

- Support leaders in and advocates for vulnerable communities with tangible resources that include not only money, but also your time, expertise, and your voice

- Identify, sponsor, and mentor your colleagues of color to serve as leaders

- Acknowledge your role in preserving terms of leadership for yourself without proactively seeking more diverse voices at decision-making tables. Recognize the BIPOC voice and talent in your organization and promote or foster their roles in leadership

- Explore your own biases, uproot them, and dismantle them

- Shoulder the responsibility of learning about the roots of systemic and institutionalized racism in the United States and actively teach this history to others. Remember that it is a privilege to educate yourself about systemic and BIPOC racism, when the alternative is to experience it

- Apply an anti-racist equity lens to every decision you make and seek out structured tools to help you do this consistently and with accountability ${ }^{9}$

- Use your privilege to advocate for systematic changes in our society to truly address anti-Black racism and systemic racism, as well as the social determinants of health

We are tired of performative hashtags instead of intentional anti-racist measures; we are tired of calling out new names of unnecessary deaths due to entrenched racist policies. Yet, we remain hopeful. We hope that in listening to us, you will now actively

\section{Table 1. Antiracism, Diversity and Health Equity} Resource List

AAFP Health Equity Curricular Toolkit

https://www.aafp.org/family-physician/patient-care/the-everyoneproject/health-equity-tools.html

Edgoose J, Quiogue M, Sidhar K. How to identify, understand, and unlearn implicit bias in patient care. Fam Pract Manag. 2019;26(4): 29-33.

Campbell KM, Rodríguez JE. Mentoring underrepresented minority in medicine (URMM) students across racial, ethnic and institutional differences. J Natl Med Assoc. 2018;110(5):421-423.

Lewis $M$, Prunuske A. The development of an indigenous health curriculum for medical students. Acad Med. 2017; 92(5):641-648.

The UCLA Latino Policy and Politics Initiative Section on Health. https://latino.ucla.edu/issues/health/

Edgoose J (ed), et al. Toolkit for teaching about racism in the context of persistent health and healthcare disparities. STFM Resource Library. https://connect.stfm.org/HigherLogic/System/DownloadDocumentFile.ashx?DocumentFileKey =cf40991e-96e9-3e15-ef157 be20cb04dc1EforceDialog $=0$.

DiAngelo, Robin J. White Fragility: Why It's so Hard for White People to Talk About Racism. Boston: Beacon Press, 2018. 
engage in anti-racist education and policy change. This is how we can collectively remedy our past and bring structural, systemic, and sustainable change for our collective future. Start now-learn about racism, identify disparities in your practice, and open avenues of dialog with your colleagues, staff, and patients. See the attached resource list for examples of accessible tools and educational materials (Table 1). Let this time in history be truly progressive toward equity and justice, and not just another faltering moment.

$$
\text { Respectfully, }
$$

Your Tired Colleagues

Members of the Society of Teachers of Family Medicine Minority and Multicultural Healtb Collaborative

To read or post commentaries in response to this article, see it online at https://www.AnnFamMed.org/content/19/1/66.

Submitted June 23, 2020; submitted, revised, October 3, 2020; accepted October 22, 2020.

Key words: racism; anti-racism; racial justice; minority tax; underrepresented in medicine; health disparities; BIPOC

Acknowledgments: Dr Foster is a current participant in the Society of Teachers of Family Medicine Beginning Writing Skills for Early Career Minority Faculty Fellowship.

\section{References}

1. White-Davis T, Edgoose J, Brown Speights JS, et al. Addressing racism in medical education an interactive training module. Fam Med. 2018;50(5):364-368. https://doi.org/10.22454/ FamMed.2018.875510.
2. Pololi L, Cooper LA, Carr P. Race, disadvantage and faculty experiences in academic medicine. J Gen Intern Med. 2010;25(12):13631369. https://doi.org/10.1007/s11606-010-1478-7.

3. Kane L. 2019. The Medscape physician compensation report 2019. Accessed Sep 17, 2020. https://www.medscape.com/ slideshow/2019-compensation-overview-6011286

4. Rodríguez JE, Campbell KM, Pololi LH. Addressing disparities in academic medicine: what of the minority tax? BMC Med Educ. 2015;15:6. https://doi.org/10.1186/s12909-015-0290-9.

5. Centers for Disease Control and Prevention, National Center for Health Statistics. Weekly updates by select demographic and geographic characteristics. Accessed May 20, 2020. https://www.cdc. gov/nchs/nvss/vsrr/covid_weekly/index.htm

6. APM Research Lab Staff. The color of Coronavirus: Covid-19 deaths by race and ethnicity in the U.S. APM Reserch Lab. Published Nov 12, 2020. Accessed May 20, 2020. https://www.apmresearchlab. org/covid/deaths-by-race

7. Brown S. How COVID-19 is affecting Black and Latino families' employment and financial well-being. The Urban Wire, The Urban Institute blog. Published May 6, 2020. Accessed May 20, 2020. https://www.urban.org/urban-wire/how-covid-19-affecting-blackand-latino-families-employment-and-financial-well-being

8. Silverman H, Toropin K, Sidner S, Perro L. Navajo Nation surpasses New York state for the highest Covid-19 infection rate in the US. CNN. May 18, 2020. Accessed Jun 20, 2020. https://www.cnn. com/2020/05/18/us/navajo-nation-infection-rate-trnd/index.html

9. Balajee, SS, et al. Equity and empowerment lens (racial justice focus). Multnomah County Office of Diversity and Equity. Published 2012. Accessed Jun 22, 2020. https://multco.us/diversity-equity/ equity-and-empowerment-lens 